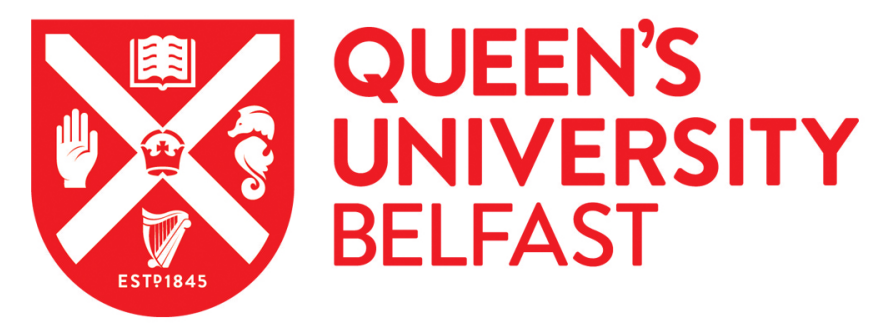

\title{
An Integrated Late Pleistocene to Holocene Tephrostratigraphic Framework for South-East and East Asia
}

Sun, C., Wang, L., Plunkett, G., Zhang, E., \& Liu, J. (2021). An Integrated Late Pleistocene to Holocene Tephrostratigraphic Framework for South-East and East Asia. Geophysical Research Letters, 48(5), [e2020GL090582]. https://doi.org/10.1029/2020GL090582

Published in:

Geophysical Research Letters

Document Version:

Peer reviewed version

Queen's University Belfast - Research Portal:

Link to publication record in Queen's University Belfast Research Portal

Publisher rights

Copyright 2021 Wiley. This work is made available online in accordance with the publisher's policies. Please refer to any applicable terms of use of the publisher.

\section{General rights}

Copyright for the publications made accessible via the Queen's University Belfast Research Portal is retained by the author(s) and / or other copyright owners and it is a condition of accessing these publications that users recognise and abide by the legal requirements associated with these rights.

Take down policy

The Research Portal is Queen's institutional repository that provides access to Queen's research output. Every effort has been made to ensure that content in the Research Portal does not infringe any person's rights, or applicable UK laws. If you discover content in the Research Portal that you believe breaches copyright or violates any law, please contact openaccess@qub.ac.uk. 
An integrated Late Pleistocene to Holocene tephrostratigraphic framework

for South-east and East Asia

3 Chunqing Sun ${ }^{a, b, c^{*}}$, Luo Wang ${ }^{\text {a,c }}$, Gill Plunkett ${ }^{\text {b }}$, Enlou Zhang ${ }^{\text {d }}$, Jiaqi Liu ${ }^{\text {a,c }}$

$4{ }^{a}$ Key Laboratory of Cenozoic Geology and Environment, Institute of Geology and Geophysics, 5 Chinese Academy of Sciences, Beijing 100029, China

6 barchaeology and Palaeoecology, School of Natural and Built Environment, Queen's University 7 Belfast, Belfast BT7 1NN, Northern Ireland, UK

$8{ }^{c}$ Innovation Academy for Earth Science, Chinese Academy of Sciences, Beijing 100029, China

$9 \quad{ }^{\mathrm{d}}$ State Key Laboratory of Lake Science and Environment, Nanjing Institute of Geography and

10 Limnology, Chinese Academy of Science, Nanjing 210008, China

12 *Corresponding author: C. Sun (suncq@mail.iggcas.ac.cn)

14 Key Points:

- We present the first high-resolution late Pleistocene to Holocene cryptotephra sequence in mainland China

- A series of key widespread late Pleistocene to Holocene tephra isochrons around East Asia is established

- We refine the dating of late Pleistocene to Holocene eruptions from Pinatubo and a volcano from southwest Luzon 


\section{Abstract}

Volcanic ash has been widely used as unique independent marker horizons for dating and synchronizing paleoenvironments and archeological records. Here, we report a series of key widespread late Pleistocene to Holocene tephras horizons from a lake sequence in southern China that have significant potential for dating and synchronizing paleoenvironmental records from East Asia. Translatitudinal paleoclimatological, paleoenvironmental and archeological correlations from the tropical Philippines, mainland China, and mid-latitude Japan are achievable through these extensively distributed tephras, including synthetic studies of the Younger Dryas and mid-Holocene climate events. Additionally, we establish refined ages for four pre-1991 Pinatubo eruptions and date three late Pleistocene Luzon eruptions based on the lake sequence age-model, which will facilitate future studies of tropical volcanic eruptions' forcing of climate change. Our results highlight the volcanic hazards around densely-populated East Asia, and bring solutions to resolving dating uncertainty in the synchronization of rapid climate events across the region.

\section{Introduction}

The Asian monsoon, comprised of East Asian and Indian subsystems, plays an important role in global hydrological and energy cycles, which affect the most densely populated regions on Earth (An et al., 2000; Wang et al., 2005). Synchronizing abrupt climate events across monsoon regions is fundamental to understanding the causal mechanisms and role of monsoon circulation in abrupt climate change. However, spatiotemporal syntheses of climate proxies are usually limited by inherent imprecision within the most common dating methods, such as ${ }^{14} \mathrm{C}$. For example, there are ongoing debates regarding the synchronization of the Holocene Optimum in the East Asian monsoon region (An et al., 2000; Zhao et al., 2009), chiefly as a result of the chronological divergence between sedimentary archives. Moreover, it is difficult to define precisely spatiotemporal leads and lags in centennial to millennial scale rapid climate events with such dating imprecision. Ascertaining independently dated marker horizons in sedimentary records can help overcome such issues.

Volcanic ash ejected from explosive eruptions can be transported several thousand kilometers from the volcanic vent, thus forming excellent regional to global independent event horizons for precisely correlating and dating terrestrial, marine, and ice core records (Lane et al., 2013; Jensen et al., 2014; Sun et al., 2014). Explosive eruptions from the western Pacific "Ring of Fire" have been demonstrated to leave deposits across large regions, such as tephra from the 1991 Pinatubo eruption which has been found in Antarctica (Wiesner et al., 1995; Cole-Dai et al., 1997). Tephras from Japanese explosive eruptions have been extensively investigated for environmental, archeological and stratigraphic studies, some extending to the east of North America and Greenland (Moriwaki et al., 2011; Mackay et al., 2016; Bourne et al., 2016; McLean et al., 2018; Albert et al., 2019). Therefore, tephra from both the Philippines and Japan can form marker horizons across a large area. Widespread tephra layers around Japan have been well outlined in the last decades (Machida 1976; Machida 1999; Machida and Arai 2003), for example, the widespread $\sim 7.3$ ka K-Ah (Kikai-Akahoya, Volcanic Explosivity Index (VEI) 7) from Kikai 
were also identified, including B-Tm (Baegdusan-Tomakomai) and QEA/B-Sg-08 (Qixiangzhan eruption ash/Baegdusan-Suigetsu-08) from Changbaishan volcano on the border between China and North Korea, and several from Ulleungdo including U-2, U-3, U-4, and perhaps U-1 (SG140433) (Sun et al., 2014; 2018; Chen et al., 2016; McLean et al., 2018; McLean et al., 2020). The $\sim 12.8 \mathrm{ka} \mathrm{Sz-S} \mathrm{(Sakurajima-Satsuma,} \mathrm{VEI} \mathrm{6)} \mathrm{from} \mathrm{Sakurajima} \mathrm{volcano} \mathrm{and} 14.9 \mathrm{ka} \mathrm{N}-\mathrm{Ym}$ (Noike-Yumugi, VEI 6) from Kuchierabujima Island are the most voluminous late Pleistocene tephras erupted on Kyushu Island, southern Japan (Moriwaki 1992; Moriwaki et al., 2011, 2016). The tephrostratigraphic framework of Lake Suigetsu is the first comprehensive Holocene sequence in Japan, and several of the aforementioned tephra layers have been identified in it (McLean et al., 2018). High-resolution radiocarbon dates provide precise age constraints for tephra layers in the Suigetsu record (Staff et al., 2011; Mclean et al., 2018). However, whether these tephra layers can be found within the region mainly affected by the East Asian monsoon has not previously been investigated, despite the potential they offer in terms of directly correlating and dating climate proxies across the region.

Explosive eruptions not only produce extensively distributed tephras, but can also have significant sub-decadal regional to global climate impacts through the injection of large amounts of sulfates and volcanic ash into the atmosphere (McCormick et al., 1995; Robock, 2000). In particular, tropical eruptions have a greater likelihood of influencing global climate because their products can spread globally, as shown by the 1991 eruption of Pinatubo in the Philippines (McCormick et al., 1995; Self et al., 1996). However, eruptive histories around South-east Asia are not well known, impeding the understanding of past tropical volcanism and climate change. The poorly constrained eruptive history of volcanoes close to densely-populated regions (e.g., Manila city, with a population of 14 million people, is less than $100 \mathrm{~km}$ from Pinatubo) also hampers the understanding and evaluation of volcanic hazards. Volcanic ash provides direct evidence for past eruptions, and distal tephras can contribute to a more complete volcanic history.

In this study, we investigate a stratigraphic sequence from a lake in southern China to explore the potential for inter-regional tephrostratigraphic correlations in eastern Asia. We identify a series of key late Pleistocene to Holocene tephras from Japanese and Philippine volcanoes that offer excellent opportunities for precise stratigraphic correlations across the East Asian monsoon region whilst also allowing us to provide new insights into the eruptive histories of individual volcanoes.

\section{Materials}

The Huguangyan maar lake (HML, $21^{\circ} 9^{\prime} \mathrm{N}, 110^{\circ} 17^{\prime} \mathrm{E}$ ) is located in the Leiqiong volcanic field, southern China (Fig. 1). The lake is $\sim 1.7 \mathrm{~km}$ in diameter, $20 \mathrm{~m}$ in maximum deep, $2.25 \mathrm{~km}^{2}$ in surface area, and surrounded by $\sim 88 \mathrm{~m}$ tuff rings. There is no surface inflow or outflow around the lake, and the catchment area comprises only the inner slopes of the crater rim (Mingram et al., 2004). Two parallel sediment cores with a composite length of $13.28 \mathrm{~m}$ core were collected from the lake in 2010. A total of 33 samples were selected for AMS ${ }^{14} \mathrm{C}$ dating, and a Bayesian age105 depth model was constructed using the P-Sequence function in OxCal 4.4 (Bronk Ramsey 2008; 106 2009) with the INTCAL20 calibration dataset (Reimer et al., 2020; Fig. 2, Table S1). 
107 Cryptotephra investigations were performed on the section $0-13 \mathrm{~m}$ using standard methods 108 (methods descriptions can be found in SI).

\section{Results}

In total, we identified 14 tephras layers characterized by distinct peaks in glass shard concentrations (Fig. 2). Extended descriptions of results can be found in SI.

\subsection{Correlations with Japan and surrounding region}

114 Four tephra layers can be correlated with eruptions from Japan and surrounding volcanoes (Fig. 115 3a, b, Table 1, SI). Trachytic HGY368 (2965-2253 cal a BP) matches the major element geochemical composition of the SG14-0433 tephra (2737-2620 cal a BP) recorded in Lake Suigetsu (McLean et al., 2018). This tephra was tentatively correlated with the U-1 eruption of Ulleungdo (Sea of Japan) because of its age and evolved trachytic glass composition, but in the absence of proximal glass data for the U-1 tephra, the correlation cannot be confirmed (McLean et al., 2018, 2020). Rhyolitic HGY763 (7499-6485 cal a BP) correlates with the widespread KAh tephra from Kikai caldera south of Kyushu Island (Machida 1999). This tephra is identified in the Lake Suigetsu record (Smith et al., 2013; Albert et al., 2019) and has been most recently dated using the Suigetsu age model to 7307-7196 cal a BP (INTCAL13; McLean et al., 2018). The rhyolitic HGY1026 (13420-12657 cal a BP) corresponds to the $12.8 \mathrm{ka} \mathrm{Sz-S}$ tephra from Sakurajima volcano situated within the Aira caldera, southern Kyushu Island, Japan. HGY995 (12738-12060 cal a BP) exhibits a very distinctive geochemical composition, and can be clearly separated from tephras from South-east Asia, central-south Japan, and Mariana-Izu-Bonin. It most closely resembles volcanic products from northern Japan (e.g., Kutcharo), although no confirmed eruptions with similar ages have been reported from this area (Fig. 3a, b; Albert et al., 2019). The origin of this tephra needs to be further investigated.

\subsection{Correlations with the Philippines}

A lack of glass geochemical datasets for Philippine eruptions hinders the firm attribution of distal tephras to volcanoes in this region. Nevertheless, four tephras with rhyolitic glass compositions can very likely be attributed to Pinatubo on the basis of their correlation with tephra from its 1991 eruption (Fig. 3c, d, Table 1, SI). The pre-1991 eruptives (i.e., the eruptions before the 1991 Pinatubo eruption; Table 1) share similar whole rock geochemical compositions with the 1991 ash, which means it is possible to compare tephras from different eruptions from this source (Luhr and Melson 1996; Newhall et al., 1996; Cole-Dai et al., 1997; Ku et al., 2008). HGY159 (927-729 cal a BP), HGY394 (3133-2719 cal a BP), and HGY702 (6166-5637 cal a BP) correspond with the Buag (800-476 cal a BP), Maraunot (3875-2342 cal a BP), and Crow Valley (6079-5004 cal a BP) eruptive epochs, respectively (Newhall et al., 1996). The glass composition of HGY1101 (14795-14080 cal a BP) also overlaps with the 1991 Pinatubo glass geochemical field, which suggests that it too derives from this source. The geochemistry of HGY1113, HGY1127 and HGY1136 ( 15-14 ka) is not consistent with known tephras around East Asia, but closely matches the $\sim 152 \mathrm{ka} \mathrm{F} 1$ tephra $(\sim 2 \mathrm{~cm}$ in thickness) recorded in marine core MD97-2142, which might suggest that it derives from the same source as the F1 tephra, 
establish the glass compositions of tephras around the Philippines (such as products from Taal and Mayon) to enable correlations between proximal and distal tephra layers in the wider region.

\section{Discussion and conclusions}

4.1 Extending and interlinking the tephrostratigraphic framework across South-east and East Asia

Cryptotephras of both tropical (Philippines) and mid-latitude (Japan and possibly South Korea) provenance identified in HML render it a key tephrostratigraphic type site of East Asia, providing the first integrated late Pleistocene to Holocene tephra framework for the region. The cryptotephra record of HML greatly extends the known distributions of several tephra layers in this region, including the Sz-S, K-Ah, SG14-0433 and the newly identified Pinatubo tephras. These widespread tephra layers can be traced from $\sim 35^{\circ} \mathrm{N}$ Japan to $\sim 20^{\circ} \mathrm{N}$ southern China, and to $\sim 15^{\circ} \mathrm{N}$ Philippines (Fig. 1).

The Sz-S tephra has been widely used as an important marker bed for dating and synchronizing paleoenvironmental and archeological archives during last deglaciation in southern Japan (Moriwaki et al., 2011, 2016). Its distribution is towards the south of Sakurajima, and mainly constrained within $\sim 200 \mathrm{~km}$ of the volcanic vent (Moriwaki 1992; Moriwaki et al., 2011; Albert et al., 2019). HML is $\sim 2,350 \mathrm{~km}$ to the southwest of Sakurajima, and the presence of Sz-S tephra in HML indicates that its dispersal was significantly greater than previous studies have suggested, perhaps extending across a large part of East Asia (Fig. 1).

The $7.3 \mathrm{ka} \mathrm{K}$-Ah tephra has served as an important mid-Holocene visible isochron in Japanese terrestrial, volcanic and archeological sediments, and has been widely used to date marine sediments (e.g., East China Sea - Machida 1999; Machida and Arai 2003; Smith et al., 2013; Moriwaki et al., 2016; McLean et al., 2018). The known southwestern limit of this tephra extends to Okinawa Trough $\sim 800 \mathrm{~km}$ away from Kikai (Li et al., 2019), but our recognition of this marker horizon in HML indicates that it can now be traced $~ 2,300 \mathrm{~km}$ from the volcanic vent. Although the source volcano of HGY368/SG14-0433 is not yet confirmed, the correlation of $\sim 2.7 \mathrm{ka} \mathrm{HGY368}$ and SG14-0433 implies that this tephra layer has been transported more than 2,900 km (from HML to Suigetsu).

Pioneering work has been carried out around Pinatubo, and various modern eruptions have been confirmed (Luhr et al., 1996; Newhall et al., 1996). The tephra from the 1991 eruption was mainly deposited in the South China Sea, and the southwestern limit of this tephra can be traced to Singapore (Wiesner et al., 1995; De Maisonneuve and Bergal-Kuvikas 2020). However, there is no evidence with which to determine the extent of the tephra distributions from pre-1991 eruptions. The confirmation of Pinatubo tephras (HGY159, HGY394, HGY702 and HGY1101) in HML demonstrates for the first time that these tephras have been transported $>1,000 \mathrm{~km}$ northwest of the volcanic vent. 
These widespread tephra layers provide opportunities to interlink volcanic eruptive histories around South-east and East Asia. For example, we can now establish that the eruption that produced the HGY368/SG14-0433 tephra occurred 300 years after the Pinatubo Maraunot period (equivalent to HGY394, section 3.2), the timing of the events not otherwise being separable on the basis of available dating evidence. The well characterized Sz-S tephra restrains the dating of the HGY995 tephra, robustly placing this event after $\sim 12.8 \mathrm{ka}$.

\subsection{Insights into Philippine volcanic eruptions}

Refining volcanic histories is crucial for the assessment of volcanic hazards, and the tephrostratigraphic records of HML can help to establish a more complete eruptive history of less studied volcanoes around South-east and East Asia, and to reveal more comprehensive tephra dispersals. We present the first identifications of distal tephras from pre-1991 Pinatubo eruptions (HGY159: 0.8 ka Buag; HGY394: 2.9 ka Maraunot; HGY702: 5.9 ka Crow Valley; Table 1) in southern China. In addition, we identify the 14.4 ka HGY1101 tephra $(14795-14080 \mathrm{cal}$ a BP) that appears to be from an unknown Pinatubo eruption. In addition to these Pinatubo-derived tephras, three 15-14 ka tephras (HGY1113, HGY1127 and HGY1136) possibly from southwest Luzon have also been identified, illustrating the frequency of large tropical eruptions from the Philippines.

Although we are unsure how many eruptive events occurred in each of pre-1991 Pinatubo eruptive epochs (Buag, Maraunot and Crow Valley), the HGY159, HGY394, and HGY702 tephras in HML likely represents large eruptions in each phase. The tephras are characterized by distinctive peaks, implying individual events of sufficient energy to disperse tephra widely. The Bayesian age-depth modeling of HML assigns relatively precise ages to these episodes. There is considerable debate about the timing of explosive activity in the Buag period (as early as 0.8 to 0.6 ka BP; Newhall et al., 1996; Gaillard et al., 2007; Rodolfo and Umbal 2008). The presence of HGY159 indicates at least one explosive eruption as early as $\sim 0.8 \mathrm{ka}$, and the phase evidently endured for more than 300 years before a late dome-forming eruption at around $0.5 \mathrm{ka}$ (Newhall et al., 1996; Gaillard et al., 2007). Notwithstanding two outlying dates of $\sim 3.9 \mathrm{ka}$ and $\sim 2.3 \mathrm{ka}$, the Maraunot period is generally dated to $\sim 3.6$ to $2.7 \mathrm{ka}$ (Newhall et al., 1996). The HGY394 tephra indicates one major event within the Maraunot period at $\sim 2.9 \mathrm{ka}$. The $~ 5.9 \mathrm{ka}$ HGY702 represents a major eruption during the Crow Valley period whose dates from proximal exposures cluster at $\sim 6.0-5.5 \mathrm{cal}$ ka BP (Newhall et al., 1996). HGY1101 similarly indicates an explosive eruption at $\sim 14.4 \mathrm{ka} \mathrm{BP}$. The absence of a proximal correlative of this age at Pinatubo may be due to poor tephra preservation. Overall, combining the dates of the distal tephras ( 0.8 ka, $\sim 2.9$ $\mathrm{ka}, \sim 5.9 \mathrm{ka}$, and $\sim 14.4 \mathrm{ka}$ ) with those of proximal eruptions at $\sim 17 \mathrm{ka}$ and $\sim 9 \mathrm{ka}$, a repose interval ranging from $\sim 3 \mathrm{ka}$ to $\sim 0.8 \mathrm{ka}$ with a decreasing trend in duration from late Pleistocene to late Holocene can be observed for the major Pinatubo eruptive episodes.

The improved dating of the Pinatubo eruptions identified in this study has implications for understanding volcanic impacts on global climate. The 1991 Pinatubo eruption had observable global climate impacts due to its large stratospheric loading of $\mathrm{SO}_{2}$ which was mainly released during a major explosive phase on $15^{\text {th }}$ June 1991 (McCormick et al., 1995; Newhall et al., 1996; 
Self et al., 1996). The magnitudes of the pre-1991 Pinatubo eruptions that produced the tephras recorded in HML were unlikely smaller than the 1991 climactic eruption and it is highly possible that these major eruptions also released significant amounts of $\mathrm{SO}_{2}$ into the atmosphere. It is reasonable, therefore, to expect that these earlier Pinatubo eruptions would have had climate impacts similar to or larger than the 1991 event. Asia

Tephra dispersal can be controlled significantly by prevailing wind as well as eruption column height (Davies et al., 2010; Smith et al., 2016). The thermal contrast between sea and land leads to different prevailing wind directions during winter and summer around East Asia, which might control tephra distributions from this area (Lau and Yang 1997; Wang et al., 2005). Long distance dispersal of K-Ah, Sz-S and SG14-0433 tephras from Japan to southern China implies a northeasterly wind that today is typical of winter months. Our findings suggest potential to find tephra from older large Japanese eruptions in longer records from the region.

The same northeasterly winds do not favor the transport of Philippine tephras to southern China, suggesting that the Pinatubo and Luzon tephras were erupted during the summer months, assuming a similar climate regime since the late Pleistocene. However, we note the absence of the 1991 Pinatubo tephra in our study, that serves to highlight the complex confluence of westerlies and easterlies during onset of summer monsoon over this region or the impacts from typhoon Yunya which passed over the Philippines during the 1991 eruption (Lau and Yang 1997; Pinatubo Volcano Observatory Team 1991). The absence of tephra from the large magnitude $\sim 9$ ka Pinatubo eruption in HML may similarly be due to unfavorable meteorological conditions at the time of the event. Seasonality cannot therefore be reliably inferred from the presence or absence of cryptotephra deposits, but future tephrochronological research may help establish if ash dispersal was more prevalent in the past, that might imply shifts in atmospheric patterns.

\subsection{Translatitudinal independent isochrons for linking rapid climate events}

Dating uncertainties in sedimentary records frequently make it difficult to determine the synchroneity of paleoclimate events across large regions. Tephra layers identified in this study comprise an important series of time-equivalent event markers that can aid the synthesis of paleoclimate records around East Asia. For example, the Younger Dryas (YD) event has been detected in Lake Suigetsu where it is dated to 12.3-11.25 ka (Nakagawa et al., 2003) and in a previous study of HML where an age estimate of 12.8-11.6 ka was suggested (Yancheva et al., 2007). Although we cannot presently confirm that the 12.4 ka HGY995 was from northern Japan or further along the Kurile arc, its geochemical composition indicates that it was from beyond southeast Asia and central-south Japan (Fig. 3a, b), implying that it too is likely a widely distributed tephra layer around East Asia erupted around the middle of the YD event. Like the translatitudinally distributed $\sim 12.8 \mathrm{ka} \mathrm{Sz-S}$ tephra erupted at around the start of the YD event, it constitutes a critical independent isochron for integrating future paleoenvironmental studies 
stretching from Japan to mainland China. Such linkages will facilitate a better understanding of the processes and mechanisms of the YD event across East Asia.

The co-occurrence of Japanese and Philippine derived tephras in southern China highlight the potential for future syntheses of paleoenvironmental archives from the tropical Philippines, to most parts of China, and to mid-latitude Japan. For example, the presence of the $7.3 \mathrm{ka} \mathrm{K}-\mathrm{Ah}$ and $~ 5.9$ ka HGY702 tephras in southern China implies that they can be used as significant translatitudinal independent marker horizons for investigating contentious leads and lags relating to various mid-Holocene rapid events from South-east to East Asia (An et al., 2000; Zhao et al., 2009).

\subsection{Implications for volcanic hazards}

The discovery of widely distributed tephras in southern China (>2,000 km away from volcanic vents for Japanese tephras, and >1,000 km for Philippine tephras; Table 1) implies that these prehistoric eruptions may have frequently impacted on some of the most densely populated parts of East Asia. Tephra deposition can directly and indirectly impact on ecosystems in both positive (e.g., soil fertilization) and negative ways (e.g. physical damage to plants, chemical alteration of water bodies), the effects varying according to distance from source (e.g., Ayris and Delmelle 2012; Arnalds 2013). Very fine ash $(<10 \mu \mathrm{m})$ poses a threat to human health (Horwell and Baxter, 2006; Newnham et al., 2010), and can travel far from the vent. Although we did not examine the $<30 \mu \mathrm{m}$ sediment fraction from HML, it is likely that some of tephras included a considerable amount of very fine ash, and the distal volcanic impacts should be considered in studies of past human cultures of the region. In the modern age, volcanic ash also poses a major risk to economies through its potential impact on transport infrastructure, as seen following the 2010 eruption of Eyjafjallajökull, Iceland (Budd et al., 2011). Compiling studies of these widespread tephras is a crucial step in understanding volcanic hazards, and our study provides the first recognition of the enormous area threatened by volcanic ash dispersal around East Asia.

\section{Acknowledgments}

This study was conducted as part of a Newton International Fellowship awarded to CS by the Royal Society and Newton Fund. Additional support was provided by the NSFC of China (grants 41772379, 41802253, 41561144010). Zhengtang Guo and Zhengfu Guo are thanked for their encouragement in this study, and Jinliang Gao for his help on sample preparations. We thank Paula Reimer and Takehiko Suzuki for their suggestions on age modelling and tephra correlations. We thank the anonymous reviewers for their constructive comments and suggestions, and the Editor Valerie Trouet for her handling of the manuscript. Data presented in this study are available on Figshare (https://figshare.com/s/f0ad9ed556f1572f140c, https://figshare.com/s/9d96c44c82eae78d4963). 


\section{References}

314 Albert, P. G., V. C. Smith, et al. 2019. Geochemical characterisation of the Late Quaternary

315 widespread Japanese tephrostratigraphic markers and correlations to the Lake Suigetsu

316 sedimentary archive (SG06 core). Quaternary Geochronology 52: 103-131.

317 Alloway, B. V., S. Andreastuti, et al. 2017. Archaeological implications of a widespread 13th

318 Century tephra marker across the central Indonesian Archipelago. Quaternary Science Reviews

319 155: 86-99.

320 An, Z., S. C. Porter, et al. 2000. Asynchronous Holocene optimum of the East Asian monsoon.

321 Quaternary Science Reviews 19: 743-762.

322 Arnalds, O. 2013. The influence of volcanic tephra (ash) on ecosystems. Advances in Agronomy $323121,331-380$.

324 Ayris, P.M. and Delmelle, P. 2012. The immediate environmental effects of tephra emission. 325 Bulletin of Volcanology 74, 1905-1936.

326 Bourne, A. J., P. M. Abbott, et al. 2016. Underestimated risks of recurrent long-range ash 327 dispersal from northern Pacific Arc volcanoes. Scientific Reports 6: 29837.

328 Bronk Ramsey, C. 2009. Bayesian analysis of radiocarbon dates. Radiocarbon 51: 337-360.

329 Bronk Ramsey, C. 2008. Deposition models for chronological records. Quaternary Science 330 Reviews 27: 42-60.

331 Budd, L., S. Griggs, et al. 2011. A fiasco of volcanic proportions? Eyjafjallajökull and the 332 closure of European airspace. Mobilities 6: 31-40.

333 Chen, X.-Y., S. P. E. Blockley, et al. 2016. Clarifying the distal to proximal tephrochronology of 334 the Millennium (B-Tm) eruption, Changbaishan Volcano, northeast China. Quaternary

335 Geochronology 33: 61-75.

336 Cole-Dai, J., E. Mosley-Thompson, et al. 1997. Quantifying the Pinatubo volcanic signal in 337 south polar snow. Geophysical Research Letters 24: 2679-2682.

338 Davies, S. M., G. Larsen, et al. 2010. Widespread dispersal of Icelandic tephra: how does the 339 Eyjafjöll eruption of 2010 compare to past Icelandic events? Journal of Quaternary Science 25:

$340 \quad 605-611$.

341 De Maisonneuve, C. B. and O. Bergal-Kuvikas 2020. Timing, magnitude and geochemistry of 342 major Southeast Asian volcanic eruptions: identifying tephrochronologic markers. Journal of 343 Quaternary Science 35: 272-287.

344 Gaillard, J., F. Delfin, et al. 2007. Planning for the future: A multidisciplinary approach to 345 reconstructing the Buag Episode of Mt Pinatubo, Philippines. In J. Grattan and R. Torrence 346 (Eds.), Living Under the Shadow: Cultural Impacts of Volcanic Eruptions (pp. 225-252). New 347 York, Routledge.

348 Horwell, C. J. and P. J. Baxter 2006. The respiratory health hazards of volcanic ash: a review for 349 volcanic risk mitigation. Bulletin of Volcanology 69: 1-24.

350 Jensen, B. J. L., S. Pyne-O’Donnell, et al. 2014. Transatlantic distribution of the Alaskan White 351 River Ash. Geology 42: 875-878. 
Ku, Y.-P., C.-H. Chen, et al. 2009. A 2 Ma record of explosive volcanism in southwestern Luzon: Implications for the timing of subducted slab steepening. Geochemistry, Geophysics, 354 Geosystems 10: Q06017. Ku, Y.-P., C.-H. Chen, et al. 2008. Determining an age for the Inararo Tuff eruption of Mt. Pinatubo, based on correlation with a distal ash layer in core MD97-2142, South China Sea. Quaternary International 178: 138-145.

Lane, C.S., Chorn, B.T., Johnson, T.C., 2013. Ash from the Toba supereruption in Lake Malawi shows no volcanic winter in East Africa at $75 \mathrm{ka}$. Proceedings of the National Academy of Sciences, 110: 8025-8029. Lau, K. M. and S. Yang 1997. Climatology and interannual variability of the southeast asian summer monsoon. Advances in Atmospheric Sciences 14: 141-162.

Lee, J., R. J. Stern, et al. 1995. Forty million years of magmatic evolution in the Mariana arc: The tephra glass record. Journal of Geophysical Research: Solid Earth 100: 17671-17687. Li, Q., Q. Zhang, et al. 2019. A new perspective for the sediment provenance evolution of the middle Okinawa Trough since the last deglaciation based on integrated methods. Earth and Planetary Science Letters 528: 115839.

Luhr, J. F. and W. G. Melson 1996. Mineral and glass compositions in June 15, 1991, pumices: Evidence for dynamic disequilibrium in the dacite of Mount Pinatubo. In C. G. Newhall and R. S. Punongbayan (Eds.), Fire and Mud: The eruptions and Lahars of Mount Pinatubo, Philippines(pp. 733-750). Seattle, University of Washington Press.

Mackay, H., P. D. M. Hughes, et al. 2016. A mid to late Holocene cryptotephra framework from eastern North America. Quaternary Science Reviews 132: 101-113.

Machida, H. 1999. The stratigraphy, chronology and distribution of distal marker-tephras in and around Japan. Global and Planetary Change 21: 71-94.

Machida, H. and F. Arai 2003. Atlas of tephra in and around Japan. Tokyo, University of Tokyo Press.

Machida, H. 1976. Stratigraphy and chronology of late Quaternary marker-tephras in Japan. Geographical Reports of Tokyo Metropolitan University 11: 109-132.

Mandeville, C. W., S. Carey, et al. 1996. Magma mixing, fractional crystallization and volatile degassing during the 1883 eruption of Krakatau volcano, Indonesia. Journal of Volcanology and Geothermal Research 74: 243-274.

McCormick, M. P., L. W. Thomason, et al. 1995. Atmospheric effects of the Mt Pinatubo eruption. Nature 373: 399-404.

McLean, D., P. G. Albert, et al. 2018. Integrating the Holocene tephrostratigraphy for East Asia using a high-resolution cryptotephra study from Lake Suigetsu (SG14 core), central Japan. Quaternary Science Reviews 183: 36-58.

McLean, D., P. G. Albert, et al. 2020. Refining the eruptive history of Ulleungdo and Changbaishan volcanoes (East Asia) over the last 86 kyrs using distal sedimentary records. Journal of Volcanology and Geothermal Research 389: 106669. 
Mingram, J., G. Schettler, et al. 2004. The Huguang maar lake - a high-resolution record of palaeoenvironmental and palaeoclimatic changes over the last 78,000 years from South China.

393 Quaternary International 122: 85-107.

394 Moriwaki, H., T. Suzuki, et al. 2011. Sakurajima-Satsuma (Sz-S) and Noike-Yumugi (N-Ym) 395 tephras: New tephrochronological marker beds for the last deglaciation, southern Kyushu, Japan. 396 Quaternary International 246: 203-212.

397 Moriwaki, H., N. Nakamura, et al. 2016. The role of tephras in developing a high-precision 398 chronostratigraphy for palaeoenvironmental reconstruction and archaeology in southern Kyushu, 399 Japan, since 30,000 cal. BP: An integration. Quaternary International 397: 79-92.

400 Moriwaki, H. 1992. Late Quaternary phreatomagmatic tephra layers and their relation to paleo401 sea levels in the area of Aira caldera, southern Kyushu, Japan. Quaternary International 13-14: 402 195-200.

403 Nakagawa, T., H. Kitagawa, et al. 2003. Asynchronous climate changes in the North Atlantic 404 and Japan curing the Last Termination. Science 299: 688-691.

405 Natawidjaja, D. H., K. Bradley, et al. 2017. Late Quaternary eruption of the Ranau Caldera and 406 new geological slip rates of the Sumatran fault zone in Southern Sumatra, Indonesia. Geoscience 407 Letters 4: 21.

408 Newhall, C. G., A. S. Daag, et al. 1996. Eruptive history of Mount Pinatubo. In C. G. Newhall 409 and R. S. Punongbayan (Eds.), Fire and Mud: The eruptions and Lahars of Mount Pinatubo, 410 Philippines (pp.165-195). Seattle, University of Washington Press.

411 Newnham, R. M., K. N. Dirks, et al. 2010. An investigation into long-distance health impacts of 412 the 1996 eruption of Mt Ruapehu, New Zealand. Atmospheric Environment 44: 1568-1578.

413 Okuno, M. 2002. Chronology of tephra layers in Southern Kyushu, SW Japan, for the last 30, 414000 Years. The Quaternary Research (Daiyonki-Kenkyu) 41: 225-236.

415 Pinatubo Volcano Observatory Team 1991. Lessons from a major eruption: Mt. Pinatubo, 416 Philippines. EOS, Transactions American Geophysical Union 72: 545-555.

417 Reimer, P. J., W. E. N. Austin, et al. 2020. The IntCal20 northern hemisphere radiocarbon age 418 calibration curve (0-55 cal kBP). Radiocarbon: 1-33.

419 Robock, A. 2000. Volcanic eruptions and climate. Review of Geophysics 38: 191-219.

420 Rodolfo, K. S. and J. V. Umbal 2008. A prehistoric lahar-dammed lake and eruption of Mount 421 Pinatubo described in a Philippine aborigine legend. Journal of Volcanology and Geothermal 422 Research 176: 432-437.

423 Scaillet, B. and B. W. Evans 1999. The 15 June 1991 eruption of Mount Pinatubo. I. phase 424 equilibria and pre-eruption $\mathrm{P}-\mathrm{T}-\mathrm{fO} 2-\mathrm{fH} 2 \mathrm{O}$ conditions of the dacite magma. Journal of Petrology 425 40: 381-411.

426 Schindlbeck, J. C., S. Kutterolf, et al. 2018. One million years tephra record at IODP Sites 427 U1436 and U1437: Insights into explosive volcanism from the Japan and Izu arcs. Island Arc 27: 428 e12244. 
Self, S., J.-X. Zhao, et al. 1996. The atmospheric impact of the 1991 Mount Pinatubo eruption. In C. G. Newhall and R. S. Punongbayan (Eds.), Fire and Mud: The eruptions and Lahars of Mount Pinatubo, Philippines (pp.1089-1116). Seattle, University of Washington Press.

432 Smith, V. C., R. A. Staff, et al. 2013. Identification and correlation of visible tephras in the Lake 433 Suigetsu SG06 sedimentary archive, Japan: chronostratigraphic markers for synchronising of east Asian/west Pacific palaeoclimatic records across the last 150 ka. Quaternary Science Reviews 67: 121-137.

Smith, V. C., R. Isaia, et al. 2016. Tephra dispersal during the Campanian Ignimbrite (Italy) eruption: implications for ultra-distal ash transport during the large caldera-forming eruption. Bulletin of Volcanology 78: 45.

439 Staff, R. A., C. Bronk Ramsey, et al. 2011. New ${ }^{14} \mathrm{C}$ determinations from Lake Suigetsu, Japan: 44012,000 to 0 Cal BP. Radiocarbon 53: 511-528.

441 Sun, C., G. Plunkett, et al. 2014. Ash from Changbaishan Millennium eruption recorded in 442 Greenland ice: Implications for determining the eruption's timing and impact. Geophysical 443 Research Letters 41: 694-701.

444 Sun, C., L. Wang, et al. 2018. Ash from the Changbaishan Qixiangzhan eruption: A new early 445 Holocene marker horizon across East Asia. Journal of Geophysical Research: Solid Earth 123: 446 6442-6450.

447 Wang, P., S. Clemens, et al. 2005. Evolution and variability of the Asian monsoon system: state of the art and outstanding issues. Quaternary Science Reviews 24: 595-629.

449 Wiesner, M. G., Y. Wang, et al. 1995. Fallout of volcanic ash to the deep South China Sea 450 induced by the 1991 eruption of Mount Pinatubo (Philippines). Geology 23: 885-888.

451 Yancheva, G., N. R. Nowaczyk, et al. 2007. Influence of the intertropical convergence zone on 452 the East Asian monsoon. Nature 445: 74-77.

453 Zhao, Y., Z. Yu, et al. 2009. Vegetation response to Holocene climate change in monsoon454 influenced region of China. Earth-Science Reviews 97: 242-256.

References From the Supporting Information

457 Bevington, P. R. 1969. Data reduction and error analysis for the physical sciences. New York: 458 McGraw Hill.

459 Blockley, S. P. E., S. D. F. Pyne-O’Donnell, et al. 2005. A new and less destructive laboratory 460 procedure for the physical separation of distal glass tephra shards from sediments. Quaternary 461 Science Reviews 24: 1952-1960.

462 Bronk Ramsey, C. 2009a. Bayesian analysis of radiocarbon dates. Radiocarbon 51: 337-360.

463 Bronk Ramsey, C. 2009b. Dealing with outliers and offsets in radiocarbon dating. Radiocarbon 464 51: 1023-1045.

465 Bronk Ramsey, C. 2008. Deposition models for chronological records. Quaternary Science 466 Reviews 27: 42-60. 
467 Chen, C.-h., T. Lee, et al. 1995. Magmatism at the onset of back-arc basin spreading in the

468 Okinawa Trough. Journal of Volcanology and Geothermal Research 69: 313-322.

469 Chen, Y.-G., W.-S. Wu, et al. 2001. A date for volcanic eruption inferred from a siltstone 470 xenolith. Quaternary Science Reviews 20: 869-873.

471 Cole-Dai, J., E. Mosley-Thompson, et al. 1997. Quantifying the Pinatubo volcanic signal in 472 south polar snow. Geophysical Research Letters 24: 2679-2682.

473 Coulter, S. E., J. R. Pilcher, et al. 2010. Testing the reliability of the JEOL FEGSEM 6500F 474 electron microprobe for quantitative major element analysis of glass shards from rhyolitic tephra.

475 Boreas 39: 163-169.

476 Kuehn, S. C., D. G. Froese, et al. 2011. The INTAV intercomparison of electron-beam 477 microanalysis of glass by tephrochronology laboratories: Results and recommendations. 478 Quaternary International 246: 19-47.

479 Le Maitre, R. W., P. Bateman, et al. 1989. A classification of igneous rocks and a glossary of 480 terms. Oxford, Blackwell Scientific.

481 Luhr, J. F. and W. G. Melson 1996. Mineral and glass compositions in June 15, 1991, pumices: 482 Evidence for dynamic disequilibrium in the dacite of Mount Pinatubo. In C. G. Newhall and R.

483 S. Punongbayan (Eds.), Fire and Mud: The eruptions and Lahars of Mount Pinatubo, 484 Philippines(pp. 733-750). Seattle, University of Washington Press.

485 McLean, D., P. G. Albert, et al. 2018. Integrating the Holocene tephrostratigraphy for East Asia using a high-resolution cryptotephra study from Lake Suigetsu (SG14 core), central Japan. Quaternary Science Reviews 183: 36-58.

488 Newhall, C. G., A. S. Daag, et al. 1996. Eruptive history of Mount Pinatubo. In C. G. Newhall 489 and R. S. Punongbayan (Eds.), Fire and Mud: The eruptions and Lahars of Mount Pinatubo, 490 Philippines (pp.165-195). Seattle, University of Washington Press.

491 Óskarsson, N., G. E. Sigvaldason, et al. 1982. A dynamic model of rift zone petrogenesis and the 492 regional petrology of Iceland. Journal of Petrology 23: 28-74.

493 Pallister, J. S., R. P. Hoblitt, et al. 1992. A basalt trigger for the 1991 eruptions of Pinatubo 494 volcano? Nature 356: 426-428.

495 Pallister, J. S., R. P. Hoblitt, et al. 1996. Magma mixing at Mount Pinatubo: petrographic and 496 chemical evidence from the 1991 deposits. In C. G. Newhall and R. S. Punongbayan (Eds.), Fire 497 and Mud: The eruptions and Lahars of Mount Pinatubo, Philippines (pp.687-731). Seattle, 498 University of Washington Press.

499 Reimer, P. J., W. E. N. Austin, et al. 2020. The IntCal20 northern hemisphere radiocarbon age 500 calibration curve (0-55 cal kBP). Radiocarbon 62: 1-33.

501 Scaillet, B. and B. W. Evans 1999. The 15 June 1991 eruption of Mount Pinatubo. I. phase 502 equilibria and pre-eruption $\mathrm{P}-\mathrm{T}-\mathrm{fO} 2-\mathrm{fH} 2 \mathrm{O}$ conditions of the dacite magma. Journal of Petrology 503 40: 381-411.

504 Wiesner, M. G., Y. Wang, et al. 1995. Fallout of volcanic ash to the deep South China Sea 505 induced by the 1991 eruption of Mount Pinatubo (Philippines). Geology 23: 885-888. 
Figure 1. Location of Huguangyan maar lake (HML), related sites, confirmed tephra dispersals by this study, and active subaerial volcanoes (ladder shapes; GVP) around East Asia. Light blue shading represents the regional expression of the monsoon over East Asia and northern Australia (Wang et al., 2005). Luzon/Philippines represent those tephras from the eruptions before the 1991 eruption of Pinatubo and southwest Luzon. SG represents Lake Suigetsu, Japan.

Figure 2. Tephrostratigraphy and chronology of Huguangyan maar lake (HML). Concentrations of glass shards against depth in the core of HML are shown: light gray shading refers to the number of glass shards per 0.5 gram of dried sediment in 5-10 cm increments; dark bands refer to glass shard concentrations in the $1 \mathrm{~cm}$ samples; and light grey dotted lines with sample codes indicate the peaks in glass shard concentration. The Bayesian age model is based upon ${ }^{14} \mathrm{C}$ dates, as well as the ages of SG14-0433 (2737-2620 cal a BP, equivalent to HGY368) and K-Ah 518 (7307-7196 cal a BP, equivalent to HGY763) tephras as derived from Lake Suigetsu (McLean et 519 al., 2018).

Figure 3. Bi-plots of glass shard compositions of cryptotephras from Huguangyan maar lake (HML), compared with published data from widely distributed tephras in the western Pacific region. Data sources: AT ( 30 ka): Smith et al., 2013; SG14-0433: McLean et al., 2018; K-Ah: Smith et al., 2013 and Albert et al., 2019; Aso-4 ( 87 ka) and Kc-2/3 (Kutcharo volcano, $\sim 85 \mathrm{ka}$ ): Albert et al., 2019; Sz-S: Albert et al., 2019 and Moriwaki et al., 2011; Izu-Bonin: Smith et al., 2013 and Schindlbeck et al., 2018; F1: Ku et al., 2009; 1991 PI (tephra from 1991 Pinatubo eruption): Luhr and Melson 1996, and Scaillet and Evans 1999; Toba including YTT (Younger Toba Tuff, 74 ka) and MTT (Middle Toba Tuff, 500 ka); Ranau ( 33 ka): Natawidjaja et al., 2017; Samalas (AD 1257): Alloway et al., 2017; Krakatau (AD 1885): Mandeville et al., 1996; Mariana: Lee et al., 1995. Error bars (2SD) for the HML tephras were calculated from secondary glass standards.

531 Table 1. Summary of the confirmed Late Pleistocene to Holocene tephras within Huguangyan 532 maar lake (HML). 
Figure 1. 


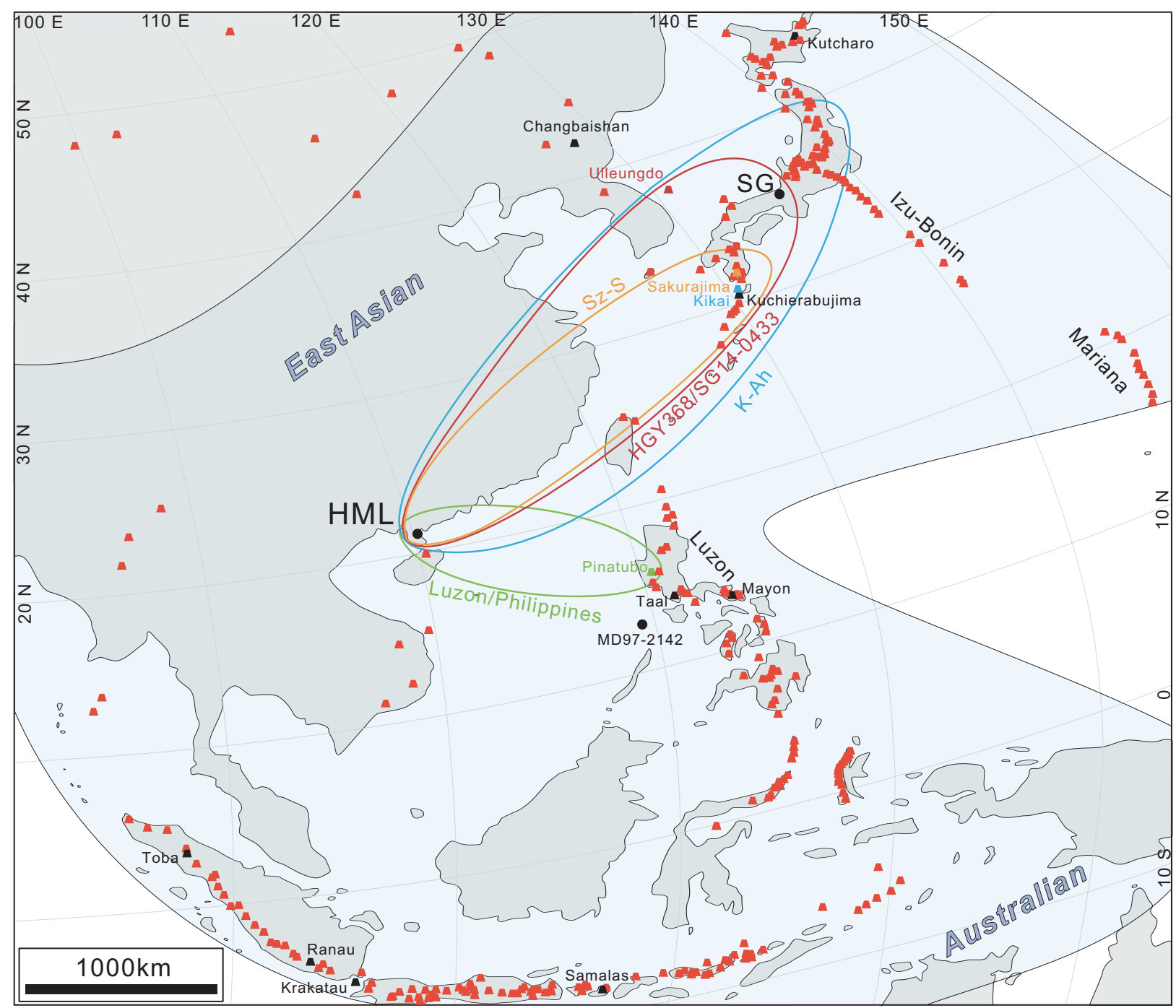


Figure 2. 


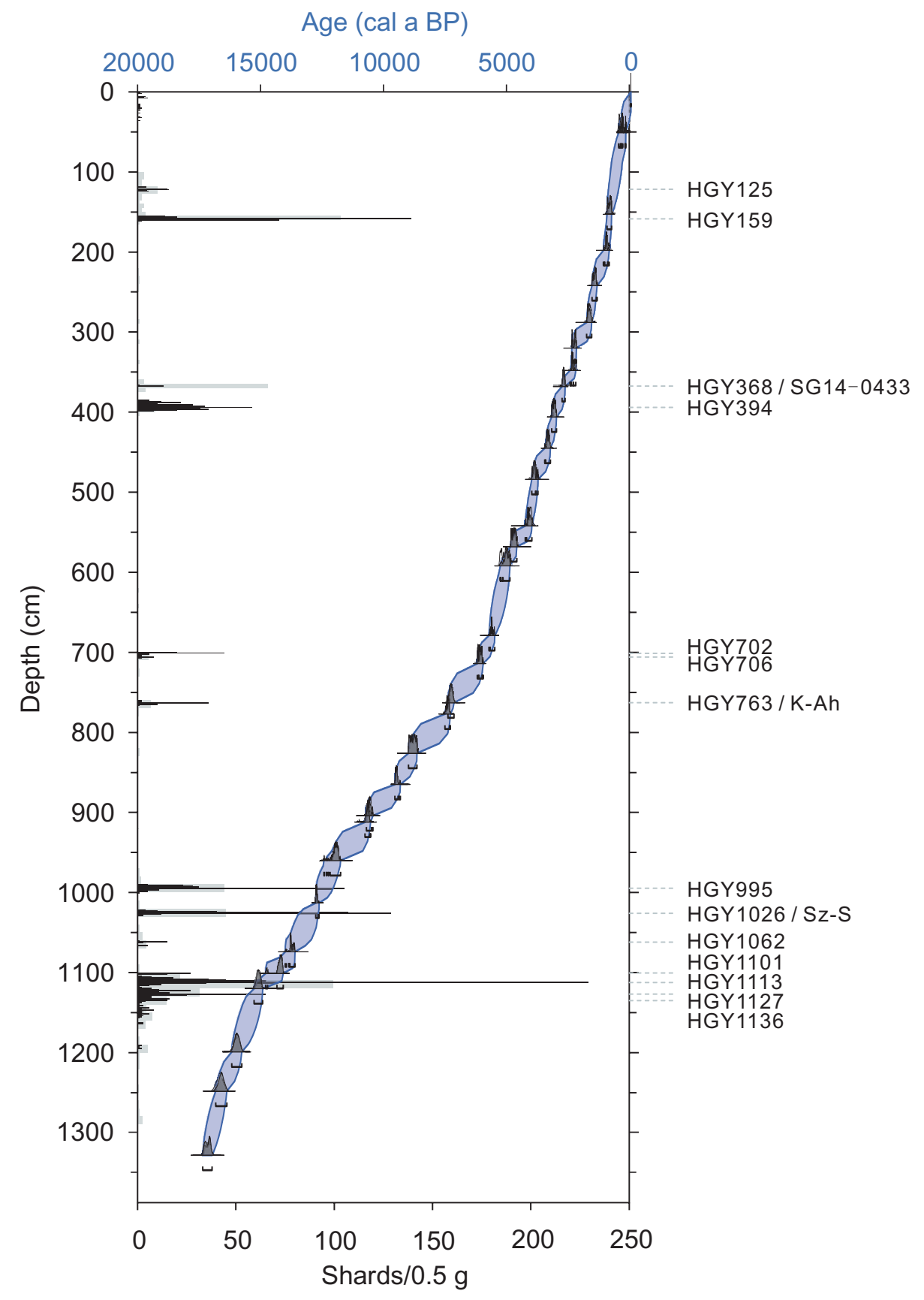


Figure 3. 

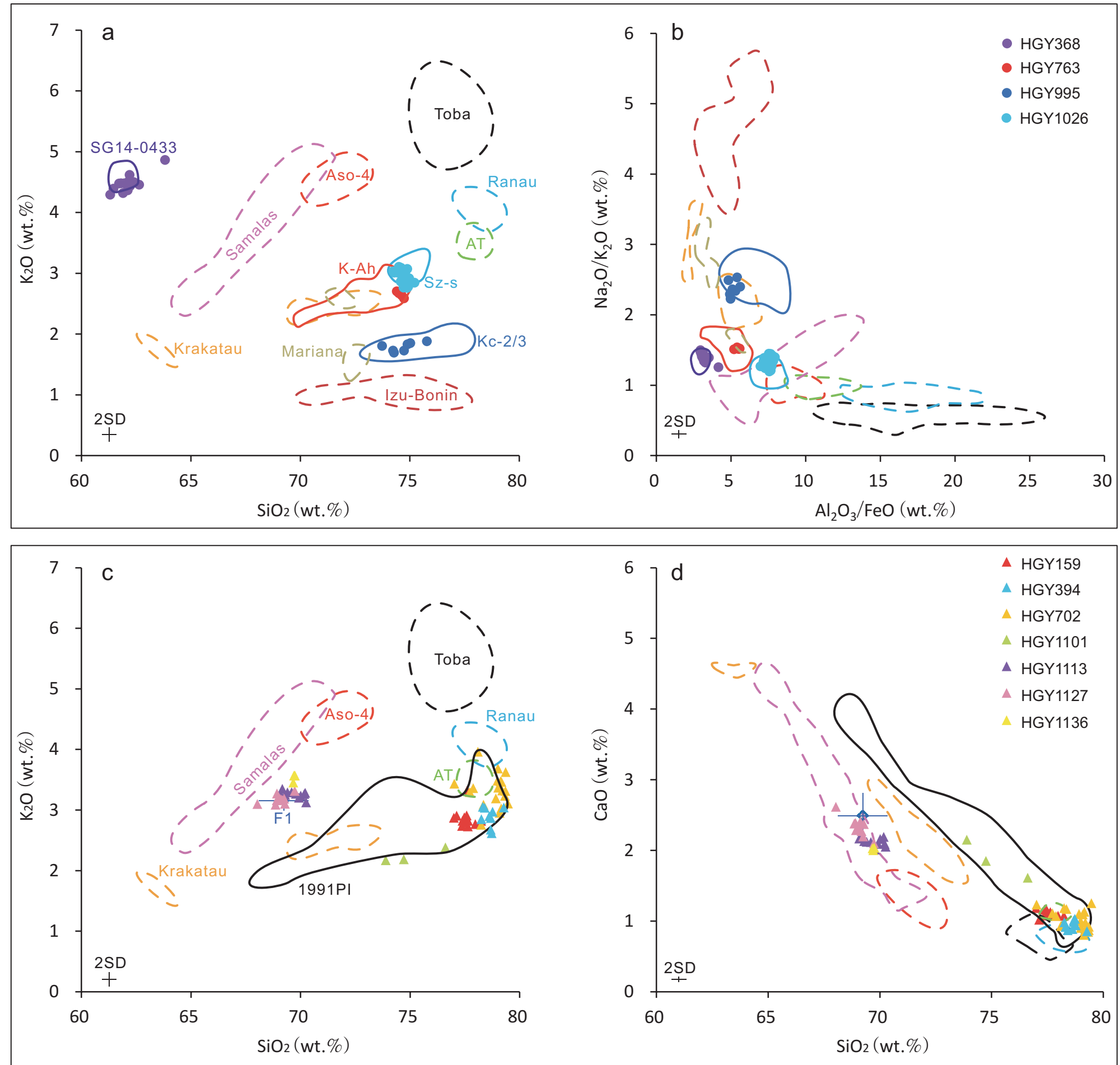
Table 1 Summary of the confirmed Late Pleistocene to Holocene tephras within Huguangyan maar lake (HML).

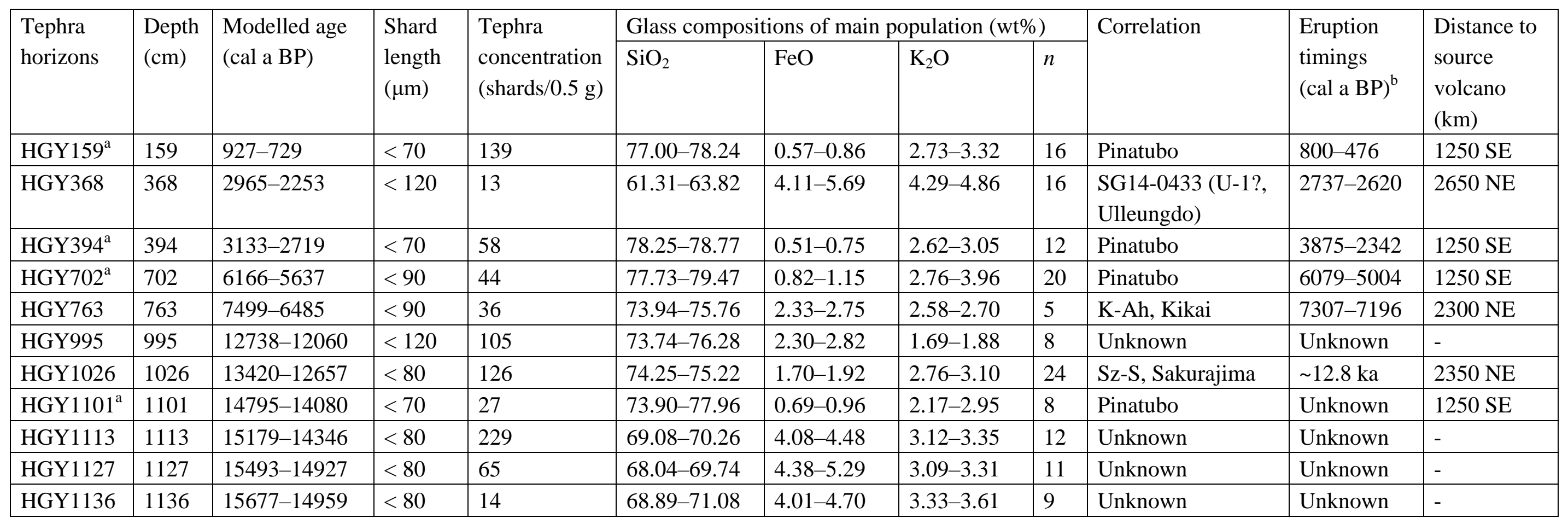

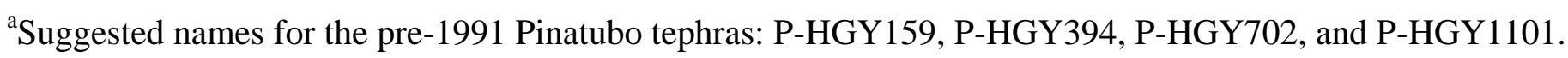

${ }^{\mathrm{b}}$ The known eruption timings are from McLean et al., 2018; Moriwaki et al., 2016; Newhall et al., 1996; Okuno 2002; Rodolfo and Umbal 2008. 